\title{
DETETION OF SPOILAGE AND FOOD POISONING BACTERIA IN SOME READY TO EAT MEAT PRODUCTS IN DAKAHLIA GOVERNORATE.
}

\author{
EL-DOSOKY, H.F.A.; SHAFIK, S. and BAHER, M. WEAM \\ Animal Health Research Institute, Mansoura branch
}

\section{ABSTRACT}

Received at: $26 / 5 / 2013$

Accepted: 15/6/2013
The aim of this work was to examine the presence of spoilage and food borne pathogens in most popular ready to eat meat products available in Dakahlia Governorate. Eighty random samples (20 each of luncheon, beefburger, sausage and shawerma) collected under aseptic condition for counting its Aerobic Plate Count (APC), counts of Staph. aureus, E. coli and Coliforms. Also the incidence of Salmonella spp. and enterotoxigenic strains of Staph. aureus reconducted. The mean count of $A P C$ were $3.6 \pm 1.3,3.5 \pm 1.8,3.6 \pm 2$ and $3.5 \pm 1 \log \mathrm{cfu} / \mathrm{gm}$, Staph. aureus count were $3.4 \pm 1.7,3.3 \pm 2,3.1 \pm 1$ and $3.2 \pm 1.6 \log \mathrm{cfu} / \mathrm{gm}$ with incidence rate of $25 \%, 15 \%, 20 \%$ and $15 \%$, while the count of $E$. coli were $3 \pm 1.5,3 \pm 1.6,3 \pm 1.7$ and $2.9 \pm 1 \log \mathrm{cfu} / \mathrm{gm}$ with incidence rate of $20 \%, 10 \%, 10 \%$ and $10 \%$ and the $M P N$ of Coliforms were $3.1 \pm 1.3,2.9 \pm 1.5,3 \pm 1$ and $2.8 \pm 1 \mathrm{log} \mathrm{cfu} / \mathrm{gm}$ with incidence rate of $20 \%, 15 \%, 10 \%$ and $10 \%$ in luncheon, beefburger, sausage and shawerma respectively, Salmonella spp. haven't been detected in any of the investigated samples. The control measures and hygienic requirement needed to produce a safe and high quality meat products were discussed and clarified to be employed.

Key words: Food poisoning bacteria, Aerobic Plate Count, Ready to eat meat.

\section{INTRODUCTION}

Meat products are ideal sources of protein when perfectly produced as well as has enough amounts of vitamins and minerals, therefore handling of meat and its products with improper heating act as an important vehicle of infection and may cause human food poisoning. Stewart et al. (2002); Gibbons et al. (2006) concluded that the possible sources of pathogens contaminated ready to eat meat products were inadequate sanitary practices or insufficient heat treatment with presence of pathogens on different surfaces occasionally contaminated the final product, Bystron et al. (2002) approved that the primary reservoirs of Staph. aureus were human skin and mucosa of nasopharyngeal cavity while Matossian and Kingcott (1979) detected food poisoning outbreak from dona kebab (a product similar to shawerma) and so Ayaz et al. (1985) added that shawerma responsible for food poisoning episodes. The occurrence of enterotoxigenic Staph. aureus in ready to eat food products has been reported in various parts all over the world (Chomvarin et al., 2006; Oh et al., 2007 and Chiang et al., 2008). Enterotoxins are groups of heat stable single protein and proteolytic enzymes produced by Staph. aureus which produce several types of enterotoxins (A,B,C,D and E) which cause symptoms of intoxications as vomiting, diarrhoea and abdominal cramping Kozacinski et al. (2005), however the enterotoxication generally is not lethal and the elderly are more susceptible than the younger individuals, the amount of enterotoxins required for intoxication about 94-184ug (Erol and Iseri,(2004) meanwhile Bergadol (1989) added that E. coli and Staph. aureus to be a major cause of food borne intoxication and its presence in food conistitute an important hygienic problem for food processors, handling and consumers. Shalaby and Zaki (2008) could isolate 3, 5 and 4 enterotoxigenic strains of Staph. aureus from shawerma, sausage and beefburger respectively and Ali and Abd-EL-Aziz (2011) could isolate Staph. aureus producing enterotoxins from shawerma. The aim of this work was to evaluate the bacterial quality of most popular ready to eat meat products available in Dakahlia Governorate to investigate their hygienic significance.

\section{MATERIALS and METHODS}

\section{Collection of samples:}

A total number of 80 random samples from ready to eat meat products (20 each of luncheon, beefburger, sausage and shawerma) were collected from different localities in Dakahlia governorate under aseptic condition, they were sent without delay to the laboratory for bacteriological examination upon receipt. 
Preparation of the samples:

Twenty five gm each of examined samples were homogenized with $225 \mathrm{ml} 0.1 \%$ peptone water in a stomacher for 2.5 minutes at $3000 \mathrm{rpm}$ and filtered through a sterile cheese cloth filter, followed by ten fold six serial dilutions in $0.1 \%$ peptone water and examined to determine the following:

1-Aerobic plate count according to $A P H A$ (2001).

2-Staph.aureus count according to $A P H A$ (2001).
3- Enumeration of Coliforms by using Most Probable Number (MPN) and Escherchia coli counts according to $F D A$ (2005).

4- Detection of Salmonella spp. according to $F D A$ (2005).

5- Detection of enterotoxigenic strains of Staph. aureus: It was done according to Donelly et al. (1967); Oda et al. (1979) and Shingaki et al. (1981) using the SET-RPLA kit for the detection of Staphylococcal enterotoxins A, B, C and D.

\section{RESULTS}

Table 1: Statistical analytical results of the examined samples expressed as $\mathrm{cfu} / \mathrm{gm}(\mathrm{n}=20)$.

\begin{tabular}{lcccc}
\hline $\begin{array}{c}\text { Microbial count } \\
\text { cfu/gm } \pm \text { S.E. }\end{array}$ & luncheon & beefburger & sausage & shawerma \\
\hline APC & $3.6 \pm 1.3$ & $3.5 \pm 1.8$ & $3.6 \pm 2$ & $3.5 \pm 1$ \\
\hline Staph. aureus count & $3.4 \pm 1.7$ & $3.3 \pm 2$ & $3.1 \pm 1$ & $3.2 \pm 1.6$ \\
\hline E. coli E. coli & $3 \pm 1.5$ & $3 \pm 1.6$ & $3 \pm 1.7$ & $2.9 \pm 1$ \\
\hline MPN of Coliforms & $3.1 \pm 1.3$ & $2.9 \pm 1.5$ & $3 \pm 1$ & $2.8 \pm 1$ \\
\hline
\end{tabular}

Table 2: Incidence of the tested bacteria in the examined +ve samples. Staph. aureus count

\begin{tabular}{|c|c|c|c|c|c|c|c|c|}
\hline \multirow{2}{*}{$\begin{array}{r}\text { +ve samples } \\
\text { microorganisms }\end{array}$} & \multicolumn{2}{|c|}{ luncheon } & \multicolumn{2}{|c|}{ beefburger } & \multicolumn{2}{|c|}{ sausage } & \multicolumn{2}{|c|}{ shawerma } \\
\hline & No & $\%$ & No & $\%$ & No & $\%$ & No & $\%$ \\
\hline Staph. aureus & 5 & $25 \%$ & 3 & $15 \%$ & 4 & $20 \%$ & 3 & $15 \%$ \\
\hline E. coli & 4 & $20 \%$ & 2 & $10 \%$ & 2 & $10 \%$ & 2 & $10 \%$ \\
\hline MPN of Coliforms & 4 & $20 \%$ & 3 & $15 \%$ & 2 & $10 \%$ & 2 & $10 \%$ \\
\hline Salmonella spp. & ND & $0 \%$ & ND & $0 \%$ & ND & $0 \%$ & ND & $0 \%$ \\
\hline
\end{tabular}

$\mathrm{APC}=$ aerobic plate count, $\mathrm{MPN}=$ most probable number of coliforms, $\mathrm{ND}=$ not detected

Table 3: Disribution of enterotoxins produced by some strains of Staph. aureus isolated from the examined samples

\begin{tabular}{|c|c|c|c|c|c|c|c|}
\hline \multirow[t]{2}{*}{ product } & \multirow{2}{*}{$\begin{array}{c}\text { No of } \\
\text { isolated } \\
\text { strains } \\
\text { No }\end{array}$} & \multicolumn{2}{|c|}{$\begin{array}{c}\text { No of strains } \\
\text { producing } \\
\text { enterotoxins }\end{array}$} & \multicolumn{4}{|c|}{$\begin{array}{c}\text { Types of } \\
\text { Produced } \\
\text { enterotoxins }\end{array}$} \\
\hline & & No & $\%$ & A & B & $\mathrm{C}$ & D \\
\hline luncheon & 5 & 2 & 40 & - & 1 & - & 1 \\
\hline beefburger & 3 & 2 & 66.6 & - & 1 & 1 & - \\
\hline sausage & 4 & 2 & 50 & 1 & - & 1 & - \\
\hline shawerma & 3 & 1 & 33.3 & - & 1 & - & - \\
\hline
\end{tabular}




\section{DISCUSSION}

Bacterial agents were incriminated in food borne infection and intoxication outbreaks in industrial and developing countries, which increased gradually Stevenson and Bernard (1995), where the revealed results gave a profile about the hygienic and microbiological status of some ready to eat meat products and showed that these products could harbor the food poisoning microorganisms easily, so the achieved results must give more attention to follow up the hygienic rules in the processing, handling and storage of such products.

Table (1) showed that the mean of $A P C$ in luncheon, beefburger, sausage and shawerma were $3.6 \pm 1.3$, $3.5 \pm 1.8, \quad 3.6 \pm 2$ and $3.5 \pm 1 \log \mathrm{cfu} / \mathrm{gm}$ respectively similarly with results achieved by Essa and Makar (2004) found $A P C 2.3 \times 10^{3} \mathrm{cfu} / \mathrm{gm}$ for beef burger and Tudor (2010) who detected $A P C$ in meat products including sausage $1.2 \times 10^{2}-4.8 \times 10^{4} \mathrm{cfu} / \mathrm{gm}$ while higher results recorded by EL-Mossalami (2009) where the $A P C$ of sausage, beefburger and shawerma sandwiches were $3.2 \pm 1.6 \times 10^{4}, 2.3 \pm 1.2 \times 10^{4}$ and $4.2 \pm$ $2.1 \times 10^{4} \mathrm{cfu} / \mathrm{gm}$ and lower one recorded by Bezerra et al. (2010) found the $A P C$ were $1.8 \mathrm{log} \mathrm{cfu} / \mathrm{gm}$ in hamburger.

The obtained results in table (1\&2) declared that the mean count of Staph. aureus were $3.4 \pm 1.7,3.3 \pm 2$, $3.1 \pm 1$ and $3.2 \pm 1.6 \mathrm{log} \mathrm{cfu} / \mathrm{gm}$ with incidence rate of $25 \%, 15 \%, 20 \%$ and $15 \%$, respectively, in this respect many researchers could isolated Staph. aureus from different meat products as AL-Cherif (1983) who found count of $10.942 \times 10^{3} \pm 4.376 \times 10^{3}$ and $98.941 \times 10^{3} \pm 57.20 \times 10^{3} \mathrm{cfu} / \mathrm{gm}$ for hamburger and

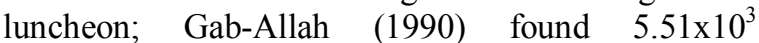
$\pm 2.64 \times 10^{3}$ cfu / gm in luncheon, Mousa (1993) detected $2.3 \times 10^{4} \mathrm{cfu} / \mathrm{gm}$ Staph. count in luncheon and coagulase positive Staph. aureus could be isolated from 18\%, Shalaby and Zaki (2008) detected Staph. aureus count in shawerma, sausage and beefburger were $9.8 \times 10^{2} \pm 0.12 \times 10^{2}, 1.2 \times 10^{3} \pm 0.24 \mathrm{x}$ $10^{2}$ and $8.3 \times 10^{2} \pm 0.09 \times 10^{2} \mathrm{cfu} / \mathrm{gm}$, EL-Mossalami (2009) could isolate Staph. aureus from sausage, beefburger and shawerma sandwiches by $3.25 \pm 6 \times 10^{3}$, $2.8 \pm 1.4 \times 10^{2}$ and $4.1 \pm 2 \times 10^{3} \mathrm{cfu} / \mathrm{gm}$, Ibrahim (2009) detected $22.85 \%$ and $31.85 \%$ of luncheon and sausage contains Staph. aureus and Saleh (2010) found $1.14 \times 10^{3} \pm 3.32 \quad \times 10^{2}, \quad 2.17 \times 10^{3} \pm 4.31 \times \quad 10^{2}$ and $2.2 \times 10^{3} \pm 4.45 \times 10^{2}$ with incidence rate of $4 \%, 12 \%$ and $16 \%$ in luncheon, beef-burger, and sausage, Ali and Abd-EL-Aziz (2011) isolate Staph. aureus from $30 \%$ of shawerma with average count of $8.98 \times 10^{3} \mathrm{cfu} / \mathrm{gm}$, while lower results recorded by Essa and Makar (2004) $1.5 \times 10^{2} \mathrm{cfu} / \mathrm{gm}$ for beef burger, Lidija Kozacinski et al. (2008) can't found Staph. aureus in fermented sausage this attributed to the application of strict hygienic measures during processing, cooking, handling and storage of these products. Table (1\&2) declared that the mean count of $E$. coli were $3 \pm 1.5,3 \pm 1.6,3 \pm 1.7$ and $2.9 \pm 1 \log$ $\mathrm{cfu} / \mathrm{gm}$ with incidence rate of $20 \%, 10 \%, 10 \%$ and $10 \%$ for luncheon, beef-burger, sausage and shawerma respectively, our results were in accordance with Edris (1993) could isolate E. coli from $20 \%$, Mousa (1993) found E. coli in $14 \%$ and Ibrahim (2009) found $E$. coli in $5.71 \%$ of examined luncheon samples, while AL-Cherif (1983) couldn't isolate $E$. coli from hamburger and luncheon.

The aforementioned results in table (2) indicated that the mean MPN of Coliforms were $3.1 \pm 1.3,2.9 \pm 1.5,3 \pm 1$ and $2.8 \pm 1 \quad \log \mathrm{cfu} / \mathrm{gm}$ with incidence rate of $20 \%, 15 \%, 10 \%$ and $10 \%$ for luncheon, sausage, beefburger and shawerma respectively these results were nearly in accordance with Lotfi et al. (1990) found $9.3 \times 10^{2} \mathrm{cfu} / \mathrm{gm}$ Coliforms in cooked meat, Francina and Alexander (1999) detected $2.5 \pm 0.3 \log \mathrm{cfu} / \mathrm{gm}$ Coliforms in the examined cooked meat products and Essa and Makar (2004) found $5.8 \times 10^{2} \mathrm{cfu} / \mathrm{gm}$ Coliforms for beef burger. These results declared that higher counts were due to postcooking contamination or unefficient cooking and improper handling. The results in table (2) declared that Salmonella spp. could n't be detected in the examined ready to eat meat product samples these results were similar to AL-Cherif (1983); Saleh (1991); Edris (1993); Mousa (1993); Kozacinski et al. (2005); Lidija Kozacinski et al. (2008); Ibrahim (2009); Bezerra et al. (2010); Saleh et al. (2010) and Tudor et al. (2010).

The results in table (3) declared that the distribution of enterotoxigenic strains of Staph. aureus were $(40 \%)$ one strain type B $(20 \%)$ and the other type D $(20 \%)$ in luncheon, in beefburger were $(66.6 \%)$ one strain type $\mathrm{B}(33.3 \%)$ and the other type $\mathrm{C}(33.3 \%)$, in sausage were $(50 \%)$ one strain type $A(25 \%)$ and the other type C $(25 \%)$ and in shawerma were one strain type B(33.3\%) Staph. enterotoxins, these results were in accordance with those reported in different parts of the world by Bergadol (1989); Erol and Iseri (2004); Kozacinski et al. (2005); Shalaby and Zaki (2008) and Ali and Abd-EL-Aziz (2011).

In conclusion, the implementation of good hygienic practices along the meat products manufacture and retail chain to ensure its safety hygienic awareness should be applied for persons whom involved in handling, preparing, processing and cooking of ready to eat meat products. Finally, Hazard Analysis Critical Control Point (HACCP) system is the suitable precaution procedure to be implemented during manufacturing and retailing of meat products to produce safe and high quality products and ensuring compliance with legalization. 


\section{REFERENCES}

AL-Cherif, A.M.A. (1983): Sanitary status of a meat factory. Thesis M.V. Sc., Meat Hygiene, Fac, Vet. Med. Cairo University.

Ali, H.; Sohaila, F. and Abd-EL-Aziz, M. Doaa (2011): Incidence of enterotoxigenic Staphylococcus aureus in some ready- to-eat meat sandwiches in Assiut City with special reference to methicillin resistant Staphylococcus aureus strains. Assiut Vet. Med. J. 57,129: 95-106.

APHA (American Public Health Association) (2001): Compendium of methods for the microbiological examination of food, Washington, DC.

Ayaz, M.; Othman, R.A.; Bahareth, T.O.; AL-Sogair, A.M. and Sawaya, W.N. (1985): Microbiological quality of shawerma in Saudia Arabia. J. Food Protection, 48: 811-814.

Bergadol, M.S. (1989): Staph. aureus in bacterial food borne pathogens, Editor Doyle M.P. Marcel Dekker press New York Occurrence of food borne pathogenic bacteria in refrigerated chicken meat. Hygiene Alimenter, 16, 100: 97-101.

Bezerra, A.C.D.; Reis, R.B. and Bastos, D.H.M. (2010): Microbiological quality of hamburger sold in the streets of Quiaba MT Brazil and vendor hygiene-awareness. Cienc. Technol. Aliment., Campinas, 30, 3: 520-524.

Bystron, J.; Kosek, P.K. and Moenda, J. (2002): Occurrence of enterotoxigenic staphylococci in white raw sausage. Medycyna Waterynaryjna, 58, 2: 995-997.

Chiang, Y.C.; Liao, W.W.; Fan, C.M.; Pai, W.Y.; Chiou, C.S. and Tsen, H.Y. (2008): PCR detection of Staphylococcal enterotoxins (SEs) $\mathrm{N}, \mathrm{O}, \mathrm{P}, \mathrm{Q}, \mathrm{R}, \mathrm{U}$ and survey of SE types in Staph. aureus isolates from food poisoning cases in Taiwan. Int. J. Food.

Chomavarin, C.; Chantarasuk, Y.; Srigulbur, S.; Chareonsudjai, S. and Chaicumper, K (2006): Enteropathogenic bacteria and enterotoxinproducing Staph. aureus isolated from ready to eat food in Khon Kaen, Thailand. Southeast Asian J. Trop. Med. Public Health, 37: 983-990.

Donelly, C.B.; Leslie, J.E.; Black, L.A. and Lewis, K.H.(1967): Serological identification of enterotoxigenic Staphylococci in cheese. Appl. Microbiol.15: 1382-1389.

Edris, A.M. (1993): Isolation and identification of $E$. coli and Salmonella in ready -to - eat meat products. Zagazig Vet. Med. J. 21, 2: 187-196.

El-Mossalami, H.H.A.; Abd-EL-Rahman, A.A.; Magdy, E.M. (2009): A study on the effect of Garlic and Nigella sativa on some food poisoning bacteria isolated from ready to eat meat sandwiches in Alexandria City. Assiut Vet. Med. J. 54,119: 140-158.

Erol, I. and Iseri, O. (2004): Staphylococcal enterotoxins, Ankara Univeritesi Veteriner Fakultesi Dergisi, 51, 3: 239-245.

Essa, H.H. and Makar, N.H. (2004): Bacteriological quality of beefburger in Assiut City. Assiut Vet. Med. J. 49, 99: 81-88.

Food and Drug Administration (FDA) (2005): Staphylococcus aureus, Bad Bug Book, Foodborne Pathogenic Microorganisms and Natural Toxins Handbook (1992/updated 2005), USFDA/FDA, Center for food safety \& Applied Nutrition.

Francina, M.M. and Alexander, H. (1999): Microbiological quality and safety of ready to eat street-vended foods in Johannesburg, South Africa. J. of food protection, 62, 11: 1278-1284.

Gab-Allah, H.M. (1990): Sanitary status of some meat products marketed in Sharkia Governorate. M. V. Sc. Thesis, Fac. Vet. Med. Zag. Univ.

Gibbons, T.; Adesiyun, A.; Nadira, S. and Rahaman, $S$. (2006): Investigation of possible sources of contamination of ready to eat meat products with Listeria spp. and other pathogens in meat processing plant in Trinidad. Food Microbiology. 23, 4: 359-366.

Ibrahim, M.I.A. (2009): Bacteriological quality and shelf life of some products. M.V.Sc. Thesis. Meat Hygiene, Fac. Vet. Med. Alex.

Kozacinski, L.; Drosinos, E.; Caklovica, F.; Cocolin, L.; Gasparik- Korpysa, W.; Rola, J.G. and Osek, J. (2005): Staphylococcal enterotoxins and their detection in milk and milk products. Medycyna Waterynarjna, 61, 6: 633-636.

Lidija Kozacinski; Eleftherios Drosinos; Faruk Caklovica; Luca Cocolin; Judith Gasparik Reichardt; Slavica Veskovic (2008): investigation of microbial association of traditionally fermented sausages. Food Technol. Biotechnol. 46, 1: 93-106.

Lotfi, A.U.; Youssef, Y.; Hefnawy, A.; EL-Tmawy, A.; Makie, T.J. and MacCartney, M.J. (1990): Sanitary status of meat meals in Assiut University Hospital. Assiut Vet. Med.J., 23, 46: 126-135.

Matossian, R. and Kingcott, E.W. (1979): The dona kebab a possible food poisoning hazard. Environm. Health. 86: 67-68.

Mousa, M.M.; Awad, H.A.; Yassien, M.M.; Gouda, H.I. (1993): Microbial quality of some meat products. Vet. Med. J. Giza. 41, 3: 59-62.

Oda, T.; Ohkuboty, T.; Nagai, M.; Nishimoto, Y. and Ohmaruk, K. (1979): Detection of Staphylococcal enterotoxins in food by reversed passive latex agglutination test. Ann. Rep. Fukuak City Hyg. Lab., 4: 33-37. 
Oh, S.K.; Lee, N.; Cho, Y.S.; Shin, D.B.; Choi, S.Y and Koo, M. (2007): Occurrence of toxigenic Staph. aureus in ready to eat food in Korea. J. Food Protection, 70: 1153-1158.

Saleh, E.A. (1991): Hygienic and Economic aspects affecting production and quality of some meat products. M. V. Sc. Thesis, Meat Hygiene Fac. Vet. Med. Alex. Univ.

Saleh, E.A.; Ali, H.A. and Abu-Khadra, A.M. (2010): Detection of some food poisoning microorganisms in some meat products. Alex. J. Vet. Sc. 31, 1: 27-33.

Shalaby, M. Amany and Zaki, M.S. Eman (2008): Occurrence of Staphylococcus aureus in fast food with special reference to its enterotoxigenicity. Assiut Vet. Med. J. 54, 112: 37-50.

Shingaki, A.A.; Igarashi, H.; Fujikawa, H.; Vshioda, H.; Teraayarm, T. and Sakai, S. (1981): Study on reversed passive latex agglutination for the detection of Staphylococcal enterotoxins A, B and C. Annu. Tokyo Met. Lab Pub. H1 ${ }^{\text {th }}$, $32 ; 128$.

Stevenson, K.E. and Bernard, D.T. (1995): Establishing Hazard Analysis Critical Control Point Programs a work shop Manual $2^{\text {nd }}$ Ed.p.4-15,4-20 the Food process Ors Inistitute, Washington, D.C.

Stewart, C.M.; Cole, M.B.; Legan, j.D.; Slade, L.; Vandeven, M.H. and Schaffner, D.W. (2002): Staph. aureus growth boundaries moving towards mechanistic predictive models based on solute-specific effects. Appl. Environment Microbiol., 68: 1671-1864.

Tudor, L.; Togoe, I. and Mitranescu, E. (2010): The microbiological quality analysis of some meat products traded on Bucharest markets. Lucrari Stiintifice - Universitatea de Stiinte Agricole a Banatului Timisoara, Medicina Veterinara. 40: 688-693.

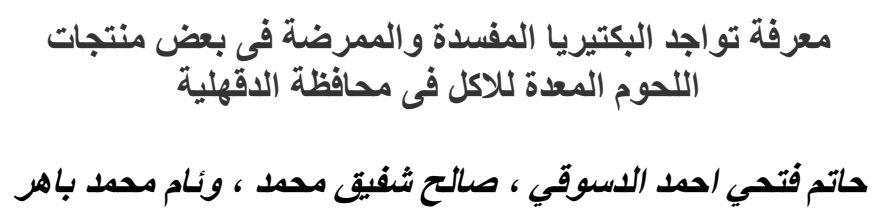

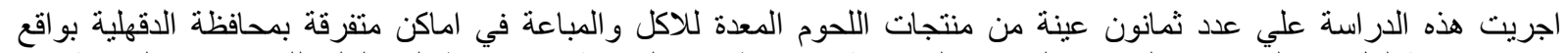

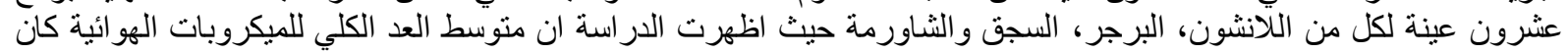

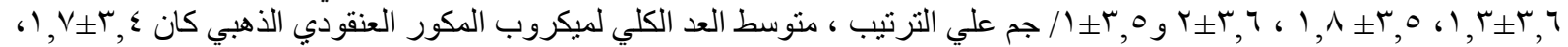

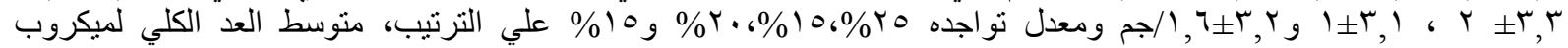

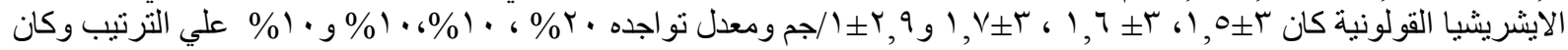

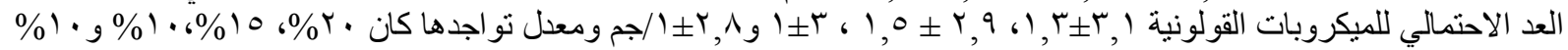

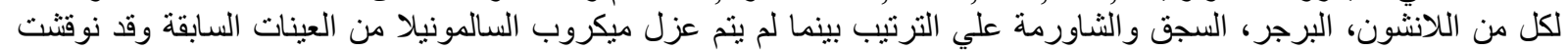

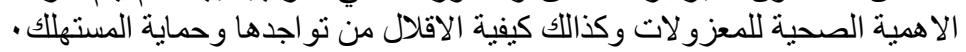

